\title{
PeER ReVieW-AN Insult To THE READER AND TO SOCIETY: MILTON'S VIEW
}

\author{
Steven James Bartlett
}

\section{An open access publication ।}

The author has chosen to issue this essay as a free open access publication under the terms of the Creative Commons Attribution-NonCommercial-NoDerivs license, which allows anyone to distribute this work without changes to its content, provided that both the author and the original URL from which this work was obtained are mentioned, that the contents of this work are not used for commercial purposes or profit, and that this work will not be used without the author's or his executor's permission in derivative works (i.e., you may not alter, transform, or build upon this work without such permission). The full legal statement of this license may be found at

http://creativecommons.org/licenses/by-nc-nd/4.0/legalcode

(c) (i) () $\odot$

EY NC ND

(C) 2017 Steven James Bartlett 


\title{
PeER ReView-
}

\section{AN INSULT TO THE READER AND TO SOCIETY: MILTON'S VIEW}

\author{
Steven James Bartlett
}

Peer review is, with near universality, now insisted upon as required pre-certification before a work can be published - allegedly, and questioningly, serving as a stamp of approval that assures the reader of its quality, validity, and accuracy. Today's peer review is different in substance, but not in form, from the pre-publication censorship that so enraged Milton and led him to write his Areopagitica. The position he took nearly four hundred years ago reminds us that pre-publication restraint is the expression of the interlinked fears of nonconformity, of the vulnerability of professional territorial turf, of disturbance of the status quo, and fear of independence of thought and resulting innovation. We are reminded that the principal target of intellectual suppression is the creative mind.

Give me the liberty to know, to utter and to argue freely according to conscience, above all liberties.

I fear yet this iron yoke of outward conformity hath left a slavish print upon our necks....

- Milton, Areopagitica

ilton wrote his Areopagitica: A Speech of Mr. John Milton for the Liberty of
Unlicensed Printing as an address in 1644 to the High Court of Parlia-
ment. His essay is commonly remembered as both an eloquent and impassioned defense of the freedom of the press, and a defense of books. But more than this, at its heart it is an argument against restraint upon an author's right to publish his thoughts, reasoning, and opinions. Central to Milton's argument are subordi- 
nate observations and claims that attack the qualifications of what today we call peer reviewers, whose role in certifying what ought to be published we not only have accepted, but have raised on a dais, judging any work, journal, or book that has not run the gamut of peer review to be of lesser quality, and therefore unlikely to be worth our time, interest, or investment of effort to read it. Further related to Milton's antipeer-review position, if he were alive today to propound it, are his observations about readers who cannot think for themselves and about their encompassing hyperanxious if not paranoidally conformist society. Such readers and tradition-shackled society are portrayed as subscribers to uncontested belief in the need for prepublication scrutiny by an army of professional examiners, whose duty it is to filter what, from their professedly authoritative point of view, is worth publishing and what is not. Milton shared his thoughts about the resulting process of scrutinizing works before their publication can be permitted, a process that confers upon those that pass, a publicly authorized stamp of approval, and he described his observations of those individuals who serve in the capacity of pre-publication examiners. These thoughts and observations have too long been sidelined and forgotten, and I would like to bring them back into clear focus here.

The suppression of printing through censorship already had a long history; at the time when Milton wrote his Areopagitica, the situation was complex and unsettling. The Star Chamber, in 1637, had passed a decree that straight-jacketed authors and printers in the severest ways possible. ${ }^{1}$ To get a sense of the throttling stricture placed on authors and their publishers, here is but one paragraph from that decree, which stipulated

that no person or persons whatsoever, shall at any time print or cause to be imprinted, any book or pamphlet whatsoever, unless the same book or pamphlet, and also all and every [sic] the titles, epistles, prefaces, proems, preambles, introductions, tables, dedications and other matters and things

\footnotetext{
${ }^{1}$ I do not attempt to give a full historical account here; for a summary see K. M. Lea's Introduction in Milton (1973/1644, pp. ix-xxii). For the remainder of this article, page references that appear in the text in parentheses are to this volume.
} 
lawfully licensed and authorized only by such person and persons as are hereafter expressed, and by no other, and shall be also first entered into the Register's book of the Company of Stationers; upon pain that every printer offending therein, shall be for ever hereafter disabled to use or exercise the art or mystery of printing, and receive such further punishment, as by this Court or the High Commission Court respectively, as the several causes shall require, shall be thought fitting. ${ }^{2}$

-This, of course, is censorship in its most common meaning, but as I have argued elsewhere ${ }^{3}$ censorship and peer review stand as much apart as do Siamese twins. But whether the intended roles of censorship and peer review are merely similar or identical, the two activities share a common purpose of filtering out what is judged not to be worthwhile, while allowing what is to pass and receive the required stamp of approval. The cannon shots nearly four hundred years ago that Milton directed against the censors of his day may justifiably, as we shall see, be fired again, and with much the same target in view, at today's peer reviewers and their managing editors and publishers, and at the professional groups and the general public who approve of the legitimacy and even the necessity of a process whose avowed purpose is the filtering through restraint and suppression of publication.

Milton's Areopagitica begins with a quotation from Euripides on the title page. It reads:

This is true Liberty when free-born men Having to advise the public may speak free, Which he who can, and will, deserves high praise; Who neither can nor will, may hold his peace; What can be juster in a State than this?

The title of Milton's address derives from the Areopagus, the hill outside of Athens

\footnotetext{
2 Extract from the Star Chamber Decree of 1637, Item II, quoted in Milton (1973/1644, p. 61).

${ }^{3}$ See "The Psychology of Abuse in Publishing: Peer Review and Editorial Bias" in (Bartlett 2011, Chapter 7).
} 
named after Ares, or Mars, where the ancient Greek high judicial council met to debate religious and political issues. Standing upon this symbolic hilltop, Milton had two main objectives: "to suppress the suppressors themselves" (28) through "the removal of an undeserved thraldom upon learning" (42).

Milton possessed a heightened respect, even reverence, for the value of books. It is only in the context of this degree of respect for the printed word that his antagonism toward those who would suppress their publication can be appreciated. Here is a little of that context:

... books are not absolute dead things but do contain a potency of life in them to be as active as that soul was whose progeny they are; nay, they do preserve as in a vial the purest efficacy and extraction of that living intellect that bred them. I know they are as lively and as vigorously productive as those fabulous dragon's teeth and being sown up and down, may chance to spring up armed men. And yet ... unless wariness be used, as good almost kill a man as kill a good book; who kills a man kills a reasonable creature, God's image; but he who destroys a good book, kills reason itself, kills the image of God, as it were in the eye. Many a man lives a burden to the earth; but a good book is the precious life-blood of a master-spirit, embalmed and treasured up on purpose to a life beyond life. 'Tis true, no age can restore a life, whereof perhaps there is no great loss; and revolutions of ages do not oft recover the loss of a rejected truth, for the want of which whole nations fare the worse. We should be wary therefore what persecution we raise against the living labours of public men [i.e., authors], how we spill that seasoned life of man preserved and stored up in books; since we see a kind of homicide may be thus committed, sometimes a martyrdom, and if it extend to the whole impression [a book's entire print run], a kind of massacre, whereof the execution ends not in the slaying of an elemental life but strikes at that ethereal and fifth essence, the breath of reason itself, slays an immortality rather than a life. (6)

Milton is here talking about literary murder, "a kind of homicide," an "execution," at times "a martyrdom," "a kind of massacre." Some readers will no doubt think that he made recourse to "pretty metaphors," but I take his words about literature in a literal sense, for he recognized that the printed word possessed, as it still does, the 
closest approximation to enduring communication with the future. When he spoke of the "immortality" of books, it was only here that he pushed the boundaries of realism. No book may be immortal, but some may come close - close, that is, in the human perspective, even if paltry from the cosmic.

This hallowed view of books, which can, if they are permitted, communicate to posterity in perpetuity, seems far-fetched today, as we see electronic texts, and the software and hardware required to preserve and read them, come into being and disappear before our eyes. Curators of literary archives and special collections, despite digital innovations, do still routinely regard the printed document as having the best potential to outlive us, in humble recognition of the evanescence of more sophisticated technologies. Milton had the long view, and in that view, books deserve a special form of respect.

As do their authors. And it is here, in connection with authors, that we seem to have lost that special respect, the appreciation of what dedicated authorship means, now that words can be cheaply spun off at the speed of dictation and with the ease of paste-and-insert. Authorship used to have a definite and clearly higher meaning:

When a man writes to the world he summons up all his reason and deliberation to assist him; he searches, meditates, is industrious, and likely consults and confers with his judicious friends; after all which done he takes himself to be informed in what he writes as well as any that wrote before him; if in this, the most consummate act of his fidelity and ripeness, no years, no industry, no former proof of his abilities can bring him to that state of maturity as not to be still mistrusted and suspected unless he carry all his considerate diligence, all his midnight watchings and expense of Palladian oil to the hasty view of an unleisured licenser, perhaps much his younger, perhaps far his inferior in judgement, perhaps one who never knew the labour of book-writing, and if he be not repulsed, or slighted, must appear in print like a puny with his guardian and his censor's hand on the back of his title to be his bail and surety, that he is no idiot or seducer, it cannot be but a dishonour and derogation to the author, to the book, to the privilege and dignity of learning. (24)

And here there enters upon the unwelcome intruder, the "unleisured licenser," 
who, as Milton points out, was usually recruited from the junior ranks (as he or she still is). This intruder — whose job is to suppress the publication of works he or she judges to be lacking in merit or agreement with prevailing fashion or paradigm may not only be the author's junior, but the author's inferior in various ways, not only in those ways mentioned by Milton, not only inferior in judgment and in the experience of book writing, but inferior in his or her knowledge of a discipline, in level of skill development, in breadth of perspective derived from a lifetime of research, and, even should these conditions be met, then predictably inferior in his immodest willfulness to question, criticize, correct, and tamper with the author's text. - These are all psychological consequences that can be anticipated, especially when the suppressor's identity is protected by the convenient peer reviewer's cloak of anonymity. ${ }^{4}$

Milton's psychological penetration was acute. He recognized that the criteria that inform us whether or not a book is "good" change with time and also with who does the judging. He wrote: "There is no book that is acceptable unless at certain seasons" (22), adding that the censor will judge against "any subject that was not to their palate" (9). These are important facts about the human psychological constitution. Tastes change, and "palate" is all-too-often the deciding factor in whether a reviewer will choose to suppress a work's publication. A reviewer's "palate," after all, is made up in the same way as anyone's: It is an amalgam of the beliefs the reviewer "likes," the biases and prejudices he or she "favors," and the research method and conclusions he or she "wishes" to see supported. All judgment is, in these ways, prejudicial, and few judges have the ability to transcend the limitations of the individual's, a profession's, and a society's vested interests at any particular time and place.

Given, then, the relativity of judgment and its fallibility in judging the worth of individual books, Milton went on to recognize that the value of any book is, as we might express this today, a function of the individual reader. There is no such thing as a

\footnotetext{
${ }^{4}$ Again, see Bartlett (2011, Chapter 7).
} 
book that is, in and of itself, "intrinsically bad," for even what appears at a certain time and to a particular judge to be a deficient work can sometimes be of value - to the right reader. " $[\mathrm{B}] \mathrm{ad}$ books ... to a discreet and judicious reader serve in many respects to discover, to confute, to forewarn and to illustrate" (13-14).

$[\mathrm{I}] \mathrm{f}$ it be true that a wise man like a good refiner can gather gold out of the drossiest volume and that a fool will be a fool with the best book, yea, or without book, there is no reason that we should deprive a wise man of any advantage to his wisdom while we seek to restrain from a fool that which being restrained will be no hindrance to his folly (17).

Milton was no fool: he was not advocating the prescription to publish all garbage. There is nothing in his Areopagitica that recommends against the right of an editor to reject a work the editor does not wish to publish. What Milton could not tolerate was a government's, or a society's, or a discipline's establishment of a system of prepublication filtering. And he could not tolerate that there should be appointed individuals who are to pass judgment on an author's work (as though they were an author's true peers), in an authorized system that will not permit an author to publish without the required, authorizing imprimatur.

These are not unsupported, dogmatic pronouncements on Milton's part. He saw clearly what a system of pre-publication restraint - whether we call it censorship or peer review — brings about. Look first at its effects upon the individual reviewer:

It cannot be denied but that he who is made judge to sit upon the birth or death of books whether they may be wafted into this world, or not, had need to be a man above the common measure, both studious, learned and judicious; there may be else no mean mistakes in the censure of what is passable or not, which is also no mean injury. If he be of such worth as behooves him, there cannot be a more tedious and unpleasing journeywork, a greater loss of time levied upon his head, than to be made the perpetual reader of unchosen books and pamphlets, oft-times huge volumes. There is no book that is acceptable unless at certain seasons; but to be enjoined the reading of that at all times and in a hand scarce legible, whereof three pages would not down [i.e., develop plumage] at any time in the fairest print, is an imposition which I cannot believe how he that values 
time, and his own studies, or is but of a sensible nostril should be able to endure. (22-23)

The arid routine, the quest to correct the smallest of details, to micro-manage, the almost irresistible urge to inflict upon a work the reviewer's own mark, to defend against threats to established usage, against threats to the comfortable paradigm, and against threats to vested professional interests, all of these combine to produce individuals whose mentality is that of the petty bookkeeper or accountant - in short, the very opposite of the openness of mind, the willingness to question the presumptions and style of thought of the day, an adventurous mind that receives joy in venturing beyond the confines and dictates of ruts that have been trodden already too deeply. Milton observed:

... his very office and his commission enjoins him to let pass nothing but what is vulgarly received already. Nay, which is more lamentable, if the work of any deceased author, though never so famous in his lifetime, and even to this day, come to their hands for license to be printed, or reprinted, if there be found in his book one sentence of a venturous edge, uttered in the height of zeal, and who knows whether it might not be the dictate of a divine Spirit, yet not suiting with every low decrepit humour of their own, ... they will not pardon him their dash [to strike out, delete, destroy]; the sense of that great man shall to all posterity be lost, for the fearfulness, or the presumptuous rashness of a perfunctory licenser. (25)

Milton recognized that a society that applauds a system of peer review has certain characteristics: It is insecure, fearful, and conformist, with no confidence in the critical judgment of the individual reader, and no willingness to grant the individual reader the freedom to judge freely. Such a society, which insists upon the prepublication peer review of the works of the author, who is not to be counted

fit to print his mind without a tutor and examiner, lest he should drop a schism, or something of corruption, is the greatest displeasure and indignity to a free and knowing spirit that can be put upon him. What advantage is it to be a man over it is to be a boy at school, if we have only escaped the ferular [a cane to whip students], to come un- 
der the fescue [the wood pointer used by a teacher] of an Imprimatur? (23)

The much heralded imprimatur of today's peer review brings in tow people who have the psychological qualities Milton enumerates, and reliance upon their authorized stamp of pre-publication certification becomes unavoidably entrenched in a society that has the associated characteristics that he identifies. From the resulting mentally foreshortened and confining universe in which every work must be filtered by a panels of reviewers, if it is to be respected and potentially read, the supreme injunction becomes engraved in stone that the works of authors "should not pass except their superintendence be over it, except it be sifted and strained with their strainers, that it should be uncurrent without their manual stamp" (26).

In such a context, consider the author who writes a professional article or book and submits it for publication. Milton then asks, “... should ye set an oligarchy of twenty engrossers [censors] over it, to bring a famine upon our minds again, when we shall know nothing but what is measured to us by their bushel" (37)? "We do not see that while we still affect by all means a rigid external formality we may as soon fall again into a gross conforming stupidity, a stark and dead congealment of wood and hay and stubble forced and frozen together..." (40). "Truth is compared in Scripture to a streaming fountain; if her waters flow not in a perpetual progression, they sicken into a muddy pool of conformity and tradition" (29).

A fully functioning mind does not require nor is it aided by the pre-filtering of publications. Equipped with such a mind, it is surely not an especially heavy burden to walk into any library and ignore those works that do not fill one's requirements and interests. It takes little mental effort to skip over the multitude of shallow and trivial papers that make up most of the contents of professional journals - and this, despite the fact, or perhaps because of the fact, that they pride themselves in being peer reviewed. Studies have shown that there is no quantifiable increase in quality of pub- 
lications as a result of their having run the gamut of peer review, just as there is no quantifiable decrease in their quality when publication decisions are left exclusively in the hands of a single, autocratic editor. ${ }^{5}$ More than this, there is a strong suspicion that many original, genuinely creative works inevitably fall victim to peer reviewed suppression and disappear into oblivion (here of course we can in principle acquire no quantified data). Peer review is no anodyne to assuage the pain of incompetence, no antidote to a dedication to trivialized pursuits, and it does not inoculate against the diseases of mediocrity and stupidity. ${ }^{6}$ Nor does placing publication decisions unilaterally in the hands of editors effect these desirable deterrents. Atrocious work will be published, and important work will sometimes, and perhaps far too often, fall between the cracks. One cannot dictate quality. It is rather up to the reader to find it. Milton therefore approved of "leaving it to each one's conscience to read or to lay by" (9). He repeated the recommendation of Dionysius Alexandrinus, who c. 240 advised, in the words Milton used to pass this sage message on to us: "Read any books whatever come to thy hands, for thou art sufficient both to judge aright and to examine each matter" (13).

There is an unmistakable infantilism that embraces the paternalism of preapproved, pre-filtered, pre-authorized publications. The content of articles and books stamped with today's imprimatur feels more comfortable, more reliable, more secure - a Linus blanket that brings childhood security. Milton, however, preached mental maturity, the deployment of a fully functioning adult's critical powers, a "conscience" as he called it that is able to sort the good from the bad, the beautiful from the ugly, the useful from what can be shrugged off and discarded. He therefore recommended going beyond "a perpetual childhood of prescription," and to trust in the reader "with the gift of reason to be his own chooser..." (14).

\footnotetext{
${ }^{5}$ See Bartlett (2011, Chapter 7).

${ }^{6}$ On mediocrity, see "The Psychology of Mediocrity: Internal Limitations that Block Human Development" in Bartlett (2011, Chapter 8). On stupidity, see "Moral Intelligence and the Pathology of Human Stupidity" in Bartlett (2005, Chapter 18).
} 


\section{REFERENCES}

Bartlett, Steven James (2005). The Pathology of Man: A Study of Human Evil. Springfield, IL: Charles C. Thomas.

Bartlett, Steven James (2011). Normality Does Not Equal Mental Health: The Need to Look Elsewhere for Standards of Good Psychological Health. Santa Barbara, CA: Praeger.

Milton, John (1973/1644). Areopagitica and On Education. K. M. Lea (Ed.). Oxford: Clarendon Press. 